\title{
The Impact of Hydrated Aluminosilicates Supplemented in Litter and Feed on Chicken Growth, Muscle Traits and Gene Expression in the Intestinal Mucosa
}

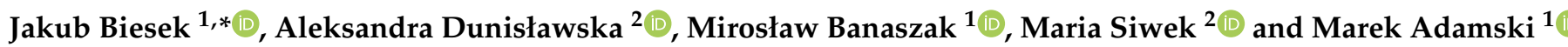 \\ 1 Department of Animal Breeding and Nutrition, Faculty of Animal Breeding and Biology, \\ UTP-University of Science and Technology in Bydgoszcz, Mazowiecka 28, 85-084 Bydgoszcz, Poland; \\ miroslaw.banaszak@utp.edu.pl (M.B.); adamski@utp.edu.pl (M.A.) \\ 2 Department of Animal Biotechnology and Genetics, UTP-University of Science and Technology in \\ Bydgoszcz, Mazowiecka 28, 85-084 Bydgoszcz, Poland; aleksandra.dunislawska@utp.edu.pl (A.D.); \\ siwek@utp.edu.pl (M.S.) \\ * Correspondence: jakub.biesek@utp.edu.pl
}

Citation: Biesek, J.; Dunisławska, A.; Banaszak, M.; Siwek, M.; Adamski, M. The Impact of Hydrated Aluminosilicates Supplemented in Litter and Feed on Chicken Growth, Muscle Traits and Gene Expression in the Intestinal Mucosa. Animals 2021, 11, 2224. https://doi.org/10.3390/ ani11082224

Academic Editors: Amélia

Camarinha-Silva and

Velmurugu Ravindran

Received: 25 June 2021

Accepted: 26 July 2021

Published: 28 July 2021

Publisher's Note: MDPI stays neutral with regard to jurisdictional claims in published maps and institutional affiliations.

Copyright: (c) 2021 by the authors. Licensee MDPI, Basel, Switzerland. This article is an open access article distributed under the terms and conditions of the Creative Commons Attribution (CC BY) license (https:// creativecommons.org/licenses/by/ $4.0 /)$.
Simple Summary: Poultry meat production has many challenges; one of them is the optimized use of natural feed and litter additives. Aluminosilicates have many properties, stimulating both the health and growth of birds and influencing the hygienic status of production. The objectives of the study were to compare growth, meat quality traits and gene expression in the intestinal mucosa of chickens, where halloysite and zeolite were added to the feed and litter simultaneously. There was a similar growth performance in all tested groups. There was no negative impact on most of the meat characteristics, and a positive effect on the water-holding capacity of the breast muscles was observed. The immunostimulatory and immunoregulatory properties of natural minerals have been demonstrated. Therefore, their use in the production of broiler chickens can be recommended.

Abstract: The aim of the study was to compare the production, muscle traits and gene expression in the intestinal mucosa of chickens supplemented with aluminosilicates in feed and litter simultaneously. A total of 300 Ross 308 were maintained for 42 days. Group 1 was the control group. In group $2,0.650 \mathrm{~kg} / \mathrm{m}^{2}$ of halloysite was added to the litter and $0.5-2 \%$ to the feed (halloysite and zeolite in a 1:1 ratio); in group 3, we added zeolite $\left(0.650 \mathrm{~kg} / \mathrm{m}^{2}\right)$ to the litter and $0.5-2 \%$ to the feed. The production parameters, the slaughter yield and analyses of muscle quality were analyzed. There was a higher body weight, body weight gain and feed conversion ratio on day 18 and 33 in group 3, and a higher feed intake on day 19-33 in groups 2 and 3 than in 1 . A lower water-holding capacity was found in the breasts of group 2 and in the legs of group 3 compared to group 1 . The expression of genes related to the immune response, host defense and intestinal barrier and nutrient sensing in the intestinal tissue was analyzed. The results show a beneficial effect on the immune status of the host without an adverse effect on the expression of genes related to intestinal tightness or nutritional processes. Due to the growth, meat characteristics and the positive impact of immunostimulant and regulating properties, aluminosilicates can be suggested as a litter and feed additive in the rearing of chickens.

Keywords: aluminosilicates; carcass; cecum; chicken; immune status; intestinal barrier; litter; meat quality

\section{Introduction}

Aluminosilicates, as hydrated volcanic rock soils, are represented by many types of mineral matter and have many applications as an additive to the litter and feed in poultry production [1], as well as in broad agricultural practices, i.e., as an addition to soil and as insecticides and pesticides in plant protection or hydroponic substrates [2]. The 
representatives of aluminosilicates that show a positive effect on many areas are halloysite and zeolite [3]. As described in the work of Eroglu et al. [2], aluminosilicates, mainly natural zeolites, have an impact on the production results of poultry and other species of farm animals, including better weight gain and a lower feed consumption ratio, as well as their use in feed improving health status. When used as a feed additive or sprinkled in loose form directly onto litter, zeolite affects the quality of bedding [4]. The quality of the litter is important for bird health and safe production, and it is mainly expressed by the ammonia (nitrogen) level and humidity, which affects the status of the soles of the feet [5]. Footpad dermatitis is a problem in the production that affects the end product and quality of the raw material (meat) and depends largely on the quality of the litter. With dry and clear litter, this problem should not occur [6]. The quality of the obtained chicken meat depends on the production results as well as the safety and hygiene status of the building [7]. The aluminosilicates can also have a positive effect on the quality of meat [8]. Mallak et al. [9] showed an improvement in the meat production and quality when using zeolite in chicken feed. Similar conclusions were reported by Safaei et al. [10] using various aluminosilicates. The halloysite has also been tested and found to be pulverized on litter to improve hygiene conditions [11].

The introduction of feed additives does not always maintain the homeostasis of the host organism and is not neutral for the intestinal microbiota of poultry. The microbiota residing in the mucosa and lumen of the gut is a key factor in the development and regulation of the immune response as well as digestion, absorption and metabolism of nutrients $[12,13]$. Intestinal epithelial cells, the mucosa and bacteria present in this environment and elements of the GALT system (gut-associated lymphoid tissue) together form the intestinal barrier. This is the most important barrier against external factors and the penetration of harmful microorganisms and the toxins they produce. Nevertheless, it allows the selective penetration of essential nutrients, electrolytes and water from the intestinal lumen into the circulatory system [14]. For sustainable poultry production, it is necessary to provide natural solutions which would support intestinal health and to boost chickens' immune system without adversely affecting weight gain or the quality of the animal raw material.

The tested hypothesis is as follows: The addition of halloysite and zeolite to feed and litter at different levels affect the production results, meat quality traits, immune status and intestinal barrier condition based on gene expression in the intestinal mucosa of broiler chickens.

The aim of the study was to compare the production results and the selected breast and leg muscle traits, and evaluate the overall immune status and intestinal barrier condition based on gene expression in the intestinal mucosa of broiler chickens, which were kept with the addition of halloysite and zeolite simultaneously in the feed and litter.

\section{Materials and Methods}

The chickens were kept in the conditions similar to commercial ones (Ross 308 requirements). According to the Directive no. 2010/63/EU, the consent of the Ethics Committee was not required. According to legal requirements, the slaughter of animals is not a procedure requiring approval from the Ethics Committee, and it was performed in accordance with the applicable rules regarding the protection of animals and their welfare at the time of slaughter. In addition, it was not necessary to obtain the consent of the Ethics Committee as dictated by the Regulation 13/2016 of the National Ethical Committee for Animal Experiments.

The presented results are part of the research and development project "Safe Farm", where the proposed use of mixtures of natural aluminosilicates was recommended and determined by experts after preliminary pilot studies [15]. The presented work is a form of application (implementation) research as a response to the needs of poultry producers. 


\subsection{Animals and Diets}

In the experiment, 300 Ross 308 commercial hybrids were used. One-day-old male chicks were divided into three equal groups composed of 10 repetitions (10 birds each). Group 1 (control) was maintained without experimental factors. In group 2, halloysite $\left(0.650 \mathrm{~kg} / \mathrm{m}^{2}\right)$ was pulverized into the litter, and in group 3 we used zeolite $\left(0.650 \mathrm{~kg} / \mathrm{m}^{2}\right)$. A total of $187.20 \mathrm{~kg}$ of halloysite and $187.20 \mathrm{~kg}$ of zeolite was used during the whole rearing period. The litter was in the form of straw pellets, which was characterized by $97.23 \%$ of dry matter and a water-holding capacity of $314.06 \mathrm{~kg} \mathrm{H}_{2} \mathrm{O} / 100 \mathrm{~kg}$. Chickens were housed according to the Ross 308 (Aviagen) requirements and management. Chickens were stocked at a maximum of $42 \mathrm{~kg} / \mathrm{m}^{2}$. Lighting was kept at a 24-h cycle during the first and last three days of life, with the interim period including a 6-h blackout. Light intensity was maximum $20 \mathrm{~lx}$. Temperature for the first three days was on average $31^{\circ} \mathrm{C}$, followed by gradual reduction to achieve average of $20^{\circ} \mathrm{C}$ from the 29th day. The humidity in the building was max. $70 \%$. Analytical composition of the granular feed is presented in Table 1. The chemical composition and physical properties of the zeolite used are described in the work of Biesek et al. [16] (same supplier). At the same time, zeolite and halloysite were added to both experimental groups. The content of added minerals in the feed and their characterization are also presented in Table 1. Zeolite and halloysite were added to the litter in a powdery form at the five time points (1st day of rearing and four feed change). The aluminosilicates were added to the feed at source as recommended by the supplier and the project evaluation experts and mixed with the feed mill from which the feed was purchased. Access to feed and water was ad libitum.

Table 1. Analytical composition of feeds for broiler chickens (4 feeding phases) and characteristics of aluminosilicates.

\begin{tabular}{|c|c|c|c|c|c|c|c|c|}
\hline \multirow{2}{*}{ Constituent [\%] } & \multicolumn{2}{|c|}{ Starter (0-11 Days) } & \multicolumn{2}{|c|}{ Grower 1 (11-18 Days) } & \multicolumn{2}{|c|}{ Grower 2 (18-33 Days) } & \multicolumn{2}{|c|}{ Finisher (34-42 Days) } \\
\hline & $C(1)^{1}$ & $E(2,3)^{2}$ & $C(1)$ & $E(2,3)$ & $\mathrm{C}(1)$ & $E(2,3)$ & $\mathrm{C}(1)$ & $E(2,3)$ \\
\hline Dry matter & 88.33 & 87.58 & 88.44 & 86.65 & 86.77 & 87.02 & 87.95 & 87.79 \\
\hline Crude ash & 4.81 & 4.81 & 4.26 & 4.94 & 4.81 & 4.93 & 4.87 & 5.14 \\
\hline Crude protein & 20.69 & 20.95 & 20.80 & 19.21 & 18.79 & 18.51 & 18.59 & 18.03 \\
\hline Crude fat & 5.45 & 5.44 & 5.46 & 6.22 & 7.40 & 8.49 & 7.29 & 7.46 \\
\hline Crude fiber & 2.17 & 3.56 & 2.57 & 3.73 & 3.31 & 3.19 & 3.41 & 3.29 \\
\hline Starch & 39.19 & 39.87 & 39.15 & 39.99 & 39.55 & 38.11 & 40.72 & 40.43 \\
\hline \multicolumn{9}{|c|}{ Addition of zeolite and halloysite to feed [\%] } \\
\hline $\begin{array}{l}\text { Zeolite and halloysite, 1:1 } \\
\text { ratio }\end{array}$ & 0 & 0.5 & 0 & 1 & 0 & 1.5 & 0 & 2 \\
\hline \multicolumn{9}{|c|}{ Characteristics of aluminosilicates [\%] } \\
\hline \multicolumn{4}{|c|}{ Zeolite } & \multicolumn{5}{|c|}{ Halloysite } \\
\hline Specific surface area & & $30-60 \mathrm{~m}^{2} / \mathrm{g}$ & & $\begin{array}{l}\text { Specific surface } \\
\text { area }\end{array}$ & & $65-8$ & & \\
\hline Bulk density & & $1.60-1.80 \mathrm{~kg} / \mathrm{m}^{3}$ & & Bulk density & & $0.70-0$ & $\mathrm{~cm}^{3}$ & \\
\hline Weight & & $2.20-2.44 \mathrm{~kg} / \mathrm{m}^{3}$ & & & & & & \\
\hline $\mathrm{SiO}_{2}$ (silicon dioxide) & & 71.30 & & Al (aluminum) & & & & \\
\hline $\mathrm{Al}_{2} \mathrm{O}_{3}$ (aluminum oxide) & & 13.10 & & Si (silicon) & & & & \\
\hline $\mathrm{CaO}$ (calcium oxide) & & 5.20 & & Ca (calcium) & & & & \\
\hline $\mathrm{K}_{2} \mathrm{O}$ (potassium oxide) & & 3.40 & & Mg (magnesium) & & & & \\
\hline $\mathrm{Fe}_{2} \mathrm{O}_{3}$ (iron (III) oxide) & & 1.90 & & $\mathrm{Na}$ (sodium) & & & & \\
\hline $\mathrm{MgO}$ (magnesium oxide) & & 1.20 & & $\mathrm{~K}$ (potassium) & & & & \\
\hline $\mathrm{Na}_{2} \mathrm{O}$ (sodium oxide) & & 1.30 & & $\mathrm{P}$ (phosphorus) & & & & \\
\hline $\mathrm{TiO}_{2}$ (titanium oxide) & & 0.30 & & Fe (iron) & & & & \\
\hline $\mathrm{Si} / \mathrm{Al}$ (silicon/aluminum) & & 5.40 & & Ti (titanium) & & & & \\
\hline Clinoptilolite & & 84.00 & & Mn (manganese) & & & & \\
\hline Cristobalite & & 8.00 & & & & & & \\
\hline Mica clay & & 4.00 & & & & & & \\
\hline Plagioclases & & 3.50 & & & & & & \\
\hline Rutile & & 0.20 & & & & & & \\
\hline
\end{tabular}

Notes: ${ }^{1,} \mathrm{C}(1)$, control group; ${ }^{2} \mathrm{E}(2,3)$, experimental groups, the feed was in the form of a complete mixture (commercial), and its composition was in line with the recommendations for feeding broiler chickens. In the experimental feeds, aluminosilicates were added in the feed mill to form a homogeneous content. The results in the table are analytical. The characteristics of aluminosilicates are from the supplier. Analytical composition of feed was carried out by FoodScan apparatus. 


\section{2. $p H$ and Total Nitrogen in the Litter}

To test the total nitrogen content and $\mathrm{pH}$ values of the litter, samples were collected on the day of insertion (1 day), days of the feed change (11, 19, 33 days) and on the day of slaughter (42 days). Bulk samples of pellets from each group, weighing $1 \mathrm{~kg}$, were collected into sterile string bags, with five replications. Sampling was performed once on the mentioned days. The $\mathrm{pH}$ was determined by the potentiometric method $[17,18]$ using the Orion $2 \mathrm{Star}$ Thermo $\mathrm{pH}$-meter, at the temperature of $20^{\circ} \mathrm{C}$, after calibration in standard buffers of known $\mathrm{pH}$ value $(2.00,4.00,7.00,9.00)$. The reading was automatic. The percentage of total nitrogen was determined according to PN-EN ISO 5983-1:2006 [19]. The determination consisted of using organic compounds of sulfuric acid in the presence of a catalyst, an alkalized solution and distillation and titration with hydrochloric acid of ammonia bound in boric acid. The FOSS Kjeltec 8400 Analyzer Unit, Sampler 8420 and FOSS Tecator Digestor apparatus were used. The analyses were performed in order to check the $\mathrm{pH}$ value trends in the litter and the presence of total nitrogen.

\subsection{Growth Performance}

Production parameters were recorded during the entire rearing period. Chickens were weighed on day 1 of hatching and on day 10, 18, 33 and 42 (BW, g). At the same time, the weight of the feed consumed (FI, g) was controlled. On the basis of the obtained data, body weight gain (BWG, g) was calculated for each rearing period according to the type of feed. The feed conversion ratio (FCR, $\mathrm{kg} / \mathrm{kg}$ ), the average daily weight gain (ADBWG, $\mathrm{g}$ ) and then the European Broiler Index (EBI) were calculated. The status of the soles of the chickens' feet was analyzed on the point scale to confirm the presence of footpad dermatitis according to the method described by Budnik [20].

\subsection{Quality Traits of Breast and Leg Muscle}

From each group, 10 chickens ( 30 in total) were selected for slaughter and assessment of physicochemical characteristics. The selection of birds for slaughter was randomized, and 1 bird was selected from the duplicate; in total 10 chickens were selected as representing the group. Chickens were marked with individual numbers. The slaughter was performed after the chickens were stunned with an electric current followed by decapitation and quick bleeding. After slaughter, the carcasses were scalded in water at a temperature of $65^{\circ} \mathrm{C}$, then plucked in a mechanical chicken plucker and gutted. Feet were cut off at the ankle joint. After this, the carcasses were cooled at $4{ }^{\circ} \mathrm{C}$ in a cold store (Hendi, Poznań, Poland). Based on the difference in body weight and carcass weight, the slaughter yield (\%) was calculated. After $24 \mathrm{~h}$, the acidity of the breast muscle was measured $\left(\mathrm{pH}_{24 \mathrm{~h}}\right)$. A pH meter (Elmetron, Zabrze, Poland) was used with a dagger electrode OSH-12-01 that was inserted into the breast muscle to a depth of $2 \mathrm{~cm}$ from the surface $(m$. pectoralis major), calibrated with known $\mathrm{pH}$ values $=4.00,7.00,9.00$. Then, the breast muscles $(\mathrm{m}$. pectoralis major and $\mathrm{m}$. pectoralis minor) and the leg muscles were dissected from the carcass for further analysis and their carcass percentage was calculated. The right breast muscles and the right leg muscles were analyzed for color using a colorimeter (Konica Minolta, Tokyo, Japan) on the CIE Lab scale, where $\mathrm{L}^{*}=$ saturation with color (lightness), $\mathrm{a}^{*}=$ saturation with red color (redness) and $\mathrm{b}^{*}=$ saturation with yellow color (yellowness). The color measurement was taken on the outer side of the tissue. The left breast muscles and the left leg muscles were ground in a meat grinder on fine meshes (Hendi, Poznań, Poland). Homogenized samples of the breast and leg muscles were used to analyze the water retention capacity. Water-holding capacity was analyzed by weighing the initial sample (M1), then placing the sample between two pieces of Whatmann blotting paper and covering it with a weight of $2 \mathrm{~kg}$ for $5 \mathrm{~min}$. After the time had elapsed, the samples (M2) were weighed, and the percentage water loss was calculated from the difference using the formula $100-\frac{\mathrm{M} 1}{\mathrm{M} 2} \times 100 \%$. Additionally, the analysis of the percentage of protein and intramuscular fat in the breast and leg muscles was analyzed using $80 \mathrm{~g}$ of ground tissue 
by FoodScan apparatus (FOSS, Hillerød, Denmark). Analyses of quality features of the breast and leg muscle were performed in 10 replications for each group.

\subsection{Gene Expression in Intestine Mucosa}

After slaughter, the cecal mucosa ( $n=5$ per group) was collected for gene expression analysis. On the basis of pilot studies (unpublished results) and the literature [21], it has been shown that the cecum provides the most information in this type of analysis. The cecum from each individual was cut lengthways after collection then rinsed in PBS and the mucosal layer was scraped with a glass slide. The collected tissues were fixed in RNA stabilizing buffer (RNA fix; EURx, Gdansk, Poland). Each tissue sample was homogenized in $1 \mathrm{~mL}$ of TRIzol reagent (MRC, Cincinnati, OH, USA) using a TissueRuptor homogenizer (Qiagen $\mathrm{GmbH}$, Hilden, Germany) which provides speed of rotation of the homogenizing tip up to 35,000 rpm. Sterile plastic tips (TissueRuptor Disposable Probe, Qiagen GmbH, Hilden, Germany) were used for homogenization. The speed of tip rotation was increased gradually to ensure proper tissue homogenization for $30 \mathrm{~s}$. A total of $200 \mu \mathrm{L}$ of chloroform was added to the homogenate, shaken and centrifuged (12,000 rpm, $15 \mathrm{~min})$. After centrifugation, the aqueous phase with the isolated RNA was collected. RNA was additionally purified using a Universal RNA Purification Kit (EURx, Gdansk, Poland) according to manufacturer's instructions. The collected aqueous phase was added to the minicolumn for filtration and centrifuged for two minutes at maximum speed. A total of $70 \%$ ethyl alcohol was added to the obtained filtrate and then transferred to a spin column to bind to the silica membrane. Membrane-bound RNA was cleaned, and the membrane was washed twice with washing buffer. RNA was eluted in a volume of $50 \mu \mathrm{L}$ of nuclease free water. Qualitative and quantitative control was performed using $2 \%$ agarose gel electrophoresis and spectrophotometer (Nanodrop 2000; Thermo Scientific, Wilmington, NC, USA). The RNA was stored at $-20{ }^{\circ} \mathrm{C}$ until further analyses were performed. Isolated RNA was reverse transcribed to cDNA (ThermoScientific, Maxima First Strand cDNA Synthesis Kit for RTqPCR; Thermo Scientific, Vilnius, Lithuania) as specified by the manufacturer. The qPCR reaction was performed using the following reaction mixture: Maxima SYBR Green qPCR Master Mix (Thermo Scientific, Vilnius, Lithuania), $140 \mathrm{ng}$ of cDNA, $1 \mu \mathrm{M}$ of forward primer and $1 \mu \mathrm{M}$ of reverse primer. Primer sequences were derived from the literature data, our previous published scientific reports or designed based on a cDNA nucleotide sequence using NCBI Primer Blast [22]. The selection of the reference genes was based on the literature $[23,24]$ and our previous molecular analyzes [21]. Analysis included the geometric mean of two independent reference genes (ACTB and G6PDH). The primer sequences are shown in Table 2. The thermal program was carried out in a LightCycler 480 instrument II (Roche Diagnostics, Basel, Switzerland). The program consisted of initial denaturation $\left(95^{\circ} \mathrm{C}, 20 \mathrm{~min}\right)$ followed by 40 cycles of amplification $\left(15 \mathrm{~s}, 95^{\circ} \mathrm{C}\right)$, annealing (20 s, melting temperature for each pair of primers) and elongation $\left(20 \mathrm{~s}, 72{ }^{\circ} \mathrm{C}\right)$. Melting curves were generated to test for the specificity of reactions at the end of the thermal cycling. Each qPCR reaction was performed in duplicate technical repetitions.

\subsection{Statistical Analyses}

\subsubsection{Growth Performance and Meat Traits}

The numerical data on the production results and meat quality traits were statistically analyzed in the Statistica 13.0 software (Statsoft, Krakow, Poland). The mean values for each examined trait and the standard error of the mean (SEM) were calculated using one-way analysis of variance (ANOVA). For this purpose, subclass statistics were selected. Statistically significant differences (total effect) were analyzed using one-dimensional results. The significance of differences between the control group and each of the experimental groups ( 1 vs 2 and 1 vs 3 ), as well as between both experimental groups ( 2 vs 3 ) was verified by the basic statistics, choosing the Student's $t$-test between the groups, assuming that the $p$ value was $<0.05$. For the $\mathrm{pH}$ value and nitrogen content in the litter, the mean values for 
groups $(1,2,3)$ and for individual days $(1,11,19,33,42)$ were calculated. These values were verified by post-hoc test $(p<0.05)$.

Table 2. Primer sequences used in RT-qPCR reaction.

\begin{tabular}{|c|c|c|c|}
\hline Gene & Name & Primer Sequences ${ }^{1}$ & References \\
\hline$A C T B$ & Actin beta & $\begin{array}{l}\text { F: CACAGATCATGTTTGAGACCTT } \\
\text { R: CATCACAATACCAGTGGTACG }\end{array}$ & [25] \\
\hline G6PDH & Glucose-6-phosphate dehydrogenase & $\begin{array}{l}\text { F: CGGGAACCAAATGCACTTCGT } \\
\text { R: GGCTGCCGTAGAGGTATGGGA }\end{array}$ & [25] \\
\hline IFNG & Interferon gamma & $\begin{array}{c}\text { F: ACACTGACAAGTCAAAGCCGC } \\
\text { R: AGTCGTTCATCGGGAGCTTG }\end{array}$ & [26] \\
\hline IL1B & Interleukin 1 beta & $\begin{array}{c}\text { F: GGAGGTTTTTGAGCCCGTC } \\
\text { R: TCGAAGATGTCGAAGGACTG }\end{array}$ & {$[21]$} \\
\hline IL10 & Interleukin 10 & $\begin{array}{c}\text { F: CATGCTGCTGGGCCTGAA } \\
\text { R: CGTCTCCTTGATCTGCTTGATG }\end{array}$ & [27] \\
\hline IL12 & Interleukin 12 & $\begin{array}{l}\text { F: TTGCCGAAGAGCACCAGCCG } \\
\text { R: CGGTGTGCTCCAGGTCTTGGG }\end{array}$ & [26] \\
\hline IL2 & Interleukin 2 & $\begin{array}{c}\text { F: GCTTATGGAGCATCTCTATCATCA } \\
\text { R: GGTGCACTCCTGGGTCTC }\end{array}$ & [28] \\
\hline IL4 & Interleukin 4 & $\begin{array}{c}\text { F: GCTCTCAGTGCCGCTGATG } \\
\text { R: GGAAACCTCTCCCTGGATGTC }\end{array}$ & [29] \\
\hline IL17 & Interleukin 17 & $\begin{array}{c}\text { F: CCGTCTTCTGCTGAGAGGAGTG } \\
\text { R: ACCGTTGTTCCGTCCCATCAC }\end{array}$ & [28] \\
\hline TNFAIP6 & Tumor necrosis factor-inducible gene 6 protein & $\begin{array}{l}\text { F: CTGGCTGTCCCTGTGTGATT } \\
\text { R: TCAGGTGCTATTGCTGCGAG }\end{array}$ & This study \\
\hline NCF1C & Neutrophil Cytosolic Factor 1C & $\begin{array}{l}\text { F: CTGTGGATGGTGTCACCGAA } \\
\text { R: TGCCATTCTCACAGCCCTAC }\end{array}$ & This study \\
\hline$A v B D 1$ & Avian beta-defensin 1 & $\begin{array}{l}\text { F: AAACCATTGTCAGCCCTGTG } \\
\text { R: TTCCTAGAGCCTGGGAGGAT }\end{array}$ & [21] \\
\hline CATHL2 & Cathelicidin & $\begin{array}{l}\text { F: AGGAGAATGGGGTCATCAGG } \\
\text { R: GGATCTTTCTCAGGAAGCGG }\end{array}$ & {$[21]$} \\
\hline MUC6 & Mucin 6 & $\begin{array}{l}\text { F: TTCAACATTCAGTTCCGCCG } \\
\text { R: TTGATGACACCGACACTCCT }\end{array}$ & {$[21]$} \\
\hline CLDN1 & Claudin 1 & $\begin{array}{l}\text { F: TCTTCATCATTGCAGGTCTGTC } \\
\text { R: AACGGGTGTGAAAGGGTCAT }\end{array}$ & {$[21]$} \\
\hline TJAP1 & Tight junction-associatedprotein 1 & $\begin{array}{l}\text { F: AGGAAGCGATGAATCCCTGTT } \\
\text { R: TCACTCAGATGCCAGATCCAA }\end{array}$ & [21] \\
\hline FFAR2 & Free fatty acid receptor 2 & $\begin{array}{l}\text { F: GCTCGACCCCTTCATCTTCT } \\
\text { R: ACACATTGTGCCCCGAATTG }\end{array}$ & {$[21]$} \\
\hline FFAR4 & Free fatty acid receptor 4 & $\begin{array}{l}\text { F: AGTGTCACTGGTGAGGAGATT } \\
\text { R: ACAGCAACAGCATAGGTCAC }\end{array}$ & [21] \\
\hline GLUT1 & Glucose transporter 1 & $\begin{array}{l}\text { F:AGATGACAGCTCGCCTGATG } \\
\text { R:GTCTTCAATCACCTTCTGCGG }\end{array}$ & {$[21]$} \\
\hline
\end{tabular}

Notes: ${ }^{1} \mathrm{~F}$, forward primer; $\mathrm{R}$, reverse primer.

\subsubsection{Relative Gene Expression and Statistical Analysis}

Relative gene expression analysis was conducted separately for each experimental group by the $\Delta \Delta \mathrm{Ct}$ method [30] using ACTB and G6PDH as reference genes (geometric mean of cycle threshold (Ct) values) [31]. Statistical analyses were performed by comparing the $\mathrm{C} t$ value of each experimental group with that of the control group by Student's $t$-test $(p<0.05)$.

\section{Results}

\subsection{Growth Performance}

During the rearing period, chicken losses were recorded at a level of less than $1 \%$. Table 3 shows the production results of the chickens. The body weight (BW) was significantly higher in group 3, where zeolite was used in the litter and halloysite with zeolite (1:1) in the feed compared to the control group. The differences are shown for the 18th day of 
rearing $(p=0.044)$ and the 33rd day $(p=0.027)$. Weight gain (BWG) was significantly higher in group 3 in comparison to group 1 in the period from 19 to 33 days of rearing, when the grower 2 feed was administered $(p=0.043)$. When comparing the weight gain expressed as average daily values, it was found that in the first group they were significantly higher than in the group $2(p=0.005)$ and in the group $3(p=0.017)$. Feed intake (FI) of the grower 1 feed was significantly higher in group 3 compared to group $1(p=0.048)$, while when using the grower 2 feed (19-33 days), FI was higher in both experimental groups: $2(p=0.018)$ and 3 ( $p=0.008$ ) compared to the control group (1). On the days 19-33 (grower 2 feed), in group 3 a significantly higher feed conversion rate (FCR) was found than in group $1(p=0.002)$. In the remaining rearing periods, no statistically significant differences were found between the control and experimental groups in BW, BWG, FI and FCR. The European Broiler Index (EBI) calculation was performed, and no statistically significant differences were found between the groups $(p=0.567)$. However, there was a slight difference in favor of the experimental groups $(2,465 ; 3,479)$ compared to group 1 (457). When analyzing the status of the soles of chickens' feet, no skin lesions were found that would indicate the presence of footpad dermatitis.

Table 3. Growth performance of broiler chickens.

\begin{tabular}{|c|c|c|c|c|c|c|c|c|}
\hline \multirow{2}{*}{ Item $^{1}$} & \multicolumn{3}{|c|}{ Group $^{2}$} & \multirow[b]{2}{*}{ SEM } & \multicolumn{4}{|c|}{$p$-Value ${ }^{3}$} \\
\hline & 1 & 2 & 3 & & Total & 1 vs 2 & 1 vs 3 & 2 vs 3 \\
\hline BW $(g)$ & & mean values & & & & & & \\
\hline 1-day old chicks & 40.56 & 40.85 & 40.30 & 0.16 & 0.399 & 0.492 & 0.555 & 0.746 \\
\hline 10 day & 261.70 & 268.44 & 270.27 & 2.45 & 0.334 & 0.229 & 0.137 & 0.745 \\
\hline 18 day & $671.16^{b}$ & $681.95^{\mathrm{ab}}$ & $695.40^{a}$ & 7.21 & 0.402 & 0.603 & 0.044 & 0.475 \\
\hline 33 day & $1960.85^{b}$ & $2048.83^{a b}$ & $2147.73^{a}$ & 34.28 & 0.079 & 0.345 & 0.027 & 0.495 \\
\hline 42 day & 3031.03 & 3177.40 & 3175.41 & 41.63 & 0.266 & 0.205 & 0.137 & 0.907 \\
\hline \multicolumn{9}{|l|}{ BWG (g) } \\
\hline $1-10$ days & 221.14 & 227.59 & 229.97 & 2.39 & 0.307 & 0.239 & 0.116 & 0.771 \\
\hline 11-18 days & 409.46 & 413.51 & 425.14 & 5.53 & 0.502 & 0.805 & 0.076 & 0.417 \\
\hline 19-33 days & $1289.69^{b}$ & $1366.88^{a b}$ & $1452.33^{a}$ & 30.98 & 0.097 & 0.367 & 0.043 & 0.768 \\
\hline 34-42 days & 1070.18 & 1128.57 & 1027.68 & 21.45 & 0.157 & 0.302 & 0.256 & 0.640 \\
\hline 1-42 days & 2990.47 & 3136.56 & 3135.12 & 41.70 & 0.267 & 0.206 & 0.138 & 0.910 \\
\hline \multicolumn{9}{|l|}{ ADBWG (g) } \\
\hline 1-10 days & 30.80 & 30.94 & 30.76 & 0.24 & 0.954 & 0.772 & 0.956 & 0.771 \\
\hline 11-18 days & 92.28 & 92.20 & 91.02 & 0.55 & 0.599 & 0.957 & 0.362 & 0.417 \\
\hline 19-33 days & 77.47 & 74.89 & 74.01 & 0.90 & 0.270 & 0.284 & 0.149 & 0.640 \\
\hline 34-42 days & 122.25 & 110.85 & 112.86 & 2.59 & 0.159 & 0.066 & 0.125 & 0.768 \\
\hline 1-42 days & $72.64^{\mathrm{a}}$ & $69.73^{b}$ & $69.59^{b}$ & 0.51 & 0.017 & 0.005 & 0.017 & 0.910 \\
\hline \multicolumn{9}{|l|}{ FI (g; per bird) } \\
\hline 1-10 days & 220.55 & 234.70 & 232.80 & 2.75 & 0.069 & 0.057 & 0.076 & 0.448 \\
\hline 11-18 days & $545.63^{b}$ & $555.90^{a b}$ & $574.90^{\mathrm{a}}$ & 6.62 & 0.191 & 0.496 & 0.048 & 0.788 \\
\hline 19-33 days & $1919.98^{b}$ & $2047.61^{a}$ & $2062.34^{\mathrm{a}}$ & 36.70 & 0.006 & 0.018 & 0.008 & 0.364 \\
\hline 34-42 days & 1818.80 & 1829.09 & 1895.28 & 21.21 & 0.288 & 0.834 & 0.104 & 0.159 \\
\hline 1-42 days & 4613.51 & 5015.33 & 4847.54 & 79.19 & 0.112 & 0.078 & 0.106 & 0.478 \\
\hline \multicolumn{9}{|l|}{ ADFI (g; per bird) } \\
\hline $1-10$ days & 30.56 & 30.00 & 30.70 & 0.32 & 0.653 & 0.563 & 0.746 & 0.448 \\
\hline $11-18$ days & 129.31 & 128.27 & 129.21 & 1.27 & 0.938 & 0.656 & 0.979 & 0.788 \\
\hline 19-33 days & 115.54 & 115.47 & 112.94 & 1.10 & 0.563 & 0.982 & 0.344 & 0.364 \\
\hline 34-42 days & 232.97 & 233.99 & 236.19 & 0.80 & 0.254 & 0.631 & 0.153 & 0.159 \\
\hline 1-42 days & 115.85 & 115.78 & 114.44 & 0.72 & 0.686 & 0.971 & 0.448 & 0.478 \\
\hline \multicolumn{9}{|l|}{ FCR $(\mathrm{kg} / \mathrm{kg})$} \\
\hline $1-10$ days & 1.00 & 1.03 & 1.01 & 0.01 & 0.396 & 0.229 & 0.536 & 0.394 \\
\hline 11-18 days & 1.33 & 1.35 & 1.35 & 0.01 & 0.856 & 0.618 & 0.592 & 0.432 \\
\hline 19-33 days & $1.70^{\mathrm{b}}$ & $1.84^{\mathrm{ab}}$ & $2.01^{\mathrm{a}}$ & 0.05 & 0.015 & 0.224 & 0.002 & 0.660 \\
\hline 34-42 days & 1.45 & 1.35 & 1.31 & 0.04 & 0.231 & 0.320 & 0.132 & 0.937 \\
\hline 1-42 days & 1.54 & 1.59 & 1.54 & 0.02 & 0.326 & 0.231 & 0.889 & 0.707 \\
\hline EBI & 457 & 465 & 479 & 8.09 & 0.567 & 0.731 & 0.274 & 0.425 \\
\hline
\end{tabular}

a b: means in the same line with no common superscript differ between groups; ${ }^{1,}$ BW, body weight; BWG, body weight gain; FI, feed intake; FCR, feed conversion ratio; ADBWG, average daily body weight gain; ADFI, average daily feed intake; EBI, European Broiler Index;

2 , control group; 2 , halloysite group; 3 , zeolite group; ${ }^{3}$, SEM, standard error of the mean; $p$-value: Total, one-dimensional results; 1 vs 2 , significance between control and halloysite groups; 1 vs 3 , significance between control and zeolite groups; 2 vs 3 , significance between halloysite and zeolite groups; 1 vs 2,1 vs 3,2 vs 3: $t$-test, $p$-value $<0.05$. 


\section{2. $\mathrm{pH}$ and Total Nitrogen in the Litter}

From Figure 1, showing the acidity levels ( $\mathrm{pH}$ values) of the litter and the contents of total nitrogen $(\%)$, no statistically significant differences are observable. The acidification decreased with the first rearing period from 7.51-7.20 (alkaline $\mathrm{pH}$ ) to 5.37-5.10 (slightly acidic $\mathrm{pH}$ ). After the feed application step with the grower 2 type, the $\mathrm{pH}$ increased in all groups (6.50-6.84). Standard error of the mean (SEM) for $\mathrm{pH}$ of the litter was 0.22 . Differences were not statistically significant between groups $(p=0.971$ for mean values of each group at whole rearing period). The temporal changes showed that the significantly highest $\mathrm{pH}$ was demonstrated on the first day of rearing (7.37), compared to the other groups $(p<0.05)$. On the day of slaughter, the average $\mathrm{pH}$ was 6.65 , with a statistically significant verification $(p<0.05)$, while the $\mathrm{pH}$ on day 11 (5.36) did not differ from the $\mathrm{pH}$ on day 19 and 33 (5.26, 5.72, respectively). A trend was noticed that in the groups with the addition of aluminosilicates, there was a quantitatively lower nitrogen content compared to the control group, and in the period from 11 to 18 days the litter contained more total nitrogen (quantitatively, $7.58-8.31 \%$ ) compared to the other rearing periods. Only on day 42 was there a higher total nitrogen content in the group where the litter contained halloysite and both minerals in the feed. Standard error of the mean (SEM) was 0.56 for the nitrogen content. No significant differences between groups were found $(p=0.999$ for mean values of each group at whole rearing period). Comparing the changes in nitrogen content in the litter during the rearing period, it was noticed that on day 1 the $\mathrm{pH}$ (3.77) was significantly higher than on days 19,33 and $42(2.46,2.67,2.88$, respectively, $p<0.05)$. On the 11 th day, the nitrogen content more than doubled (8.02), and the significance of the differences was verified at the level of $p<0.001$. (Figure 2).

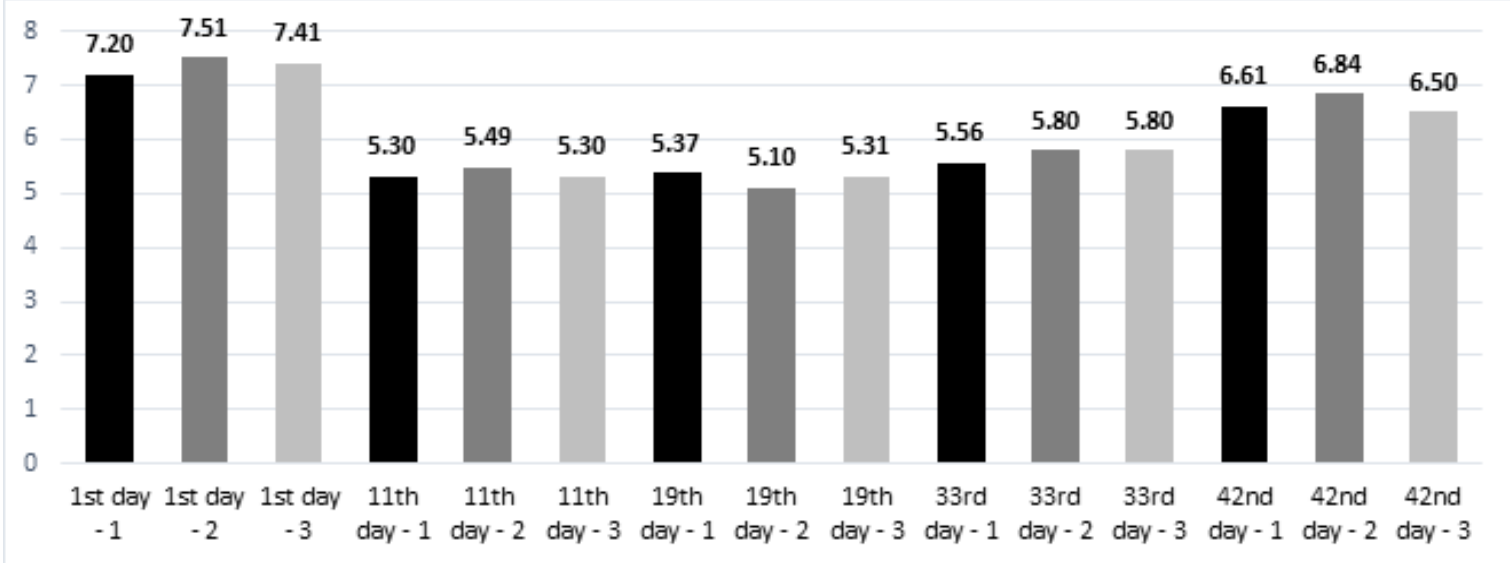

Figure 1. pH of the litter. Notes: 1-control group; 2-group with halloysite in the litter; 3-group with zeolite in the litter; 1st day—stater feed period; 11th day-grower 1 feed period; 19th day-grower 2 feed period; 33rd day-finisher feed period; 42nd day—slaughter day; sampling was performed once on the mentioned days. No significant differences between groups were found $(p>0.05)$; mean values from various days were significantly different, with $p$-value $<0.05$.

\subsection{Slaughter Yield and Some Quality Traits of Breast and Leg Muscle}

Carcass weight from group 1 was significantly lower than in group $2(p=0.015)$. The slaughter yield of chickens in all groups was similar, at the level of 75.26-77.06\%; however, no significant differences were found between the control and experimental groups $(2, p=0.057 ; 3, p=0.298)$, while the one-dimensional effect of the additives used on the slaughter yield was demonstrated $(p=0.011)$. There were no significant differences in the percentage of breast muscles in the carcass between the groups, and their value was $30.97-31.75 \%$. Similarly, no significant differences were found in the $\mathrm{pH}_{24} \mathrm{~h}$ of the breast muscles (6.07-6.15) and in the color expressed on the scale of CIE L* (49.42-52.13), a (2.25-3.18) and $\mathrm{b}^{*}(4.64-5.37)(p>0.05)$. Analyzing the results concerning the water-holding capacity (the value of water lost) of the breast muscles, a statistically significantly better 
water-holding capacity was shown in group 2 compared to group $1(p=0.012)$. The total effect on water absorption was found in the experiment $(p=0.008)$. The content of crude protein and intramuscular fat in the breast muscles was significantly different in all groups $(p<0.001)$. The control group showed significantly higher protein and lower fat content compared to groups 2 and 3. In group 3, the protein content was the lowest (Table 4). The share of leg muscles in the carcass was $19.48-20.59 \%$ in all groups $(p=0.126)$. A significantly higher lightness (higher $L^{*}$ value) was demonstrated in group 3 than that in group $1(p=0.038)$, while a higher yellowness $\left(b^{*}\right)$ was demonstrated in group 2 than that in group $1(p=0.036)$, and a total effect was also found yellowness in the muscles of the legs $(p=0.035)$. The water-holding capacity was lower in group 3 than in group $1(p=0.004)$. The protein content in the leg muscles was significantly higher in group 1 than in group $3(p<0.001)$, and lower than in group $2(p=0.003)$. On the other hand, the fat content differed between groups 1 and 2, where its content was significantly higher in the control group $(p<0.001)$. The overall effect between the groups in the chemical composition (crude protein, intramuscular fat) in the breast and leg muscles was shown to be highly significant $(p<0.001)$. Comparing the experimental groups, a significantly higher slaughter yield was shown in group 2 than in group $3(p=0.002)$, as well as a higher $L^{*}$ value and lower water loss $(p=0.005)$ and a higher protein and lower fat content $(p<0.001)$ in the breast muscles. Additionally, a higher protein and lower fat content in the leg muscles $(p<0.001)$ was found in group 2 compared to group 3. (Table 4).

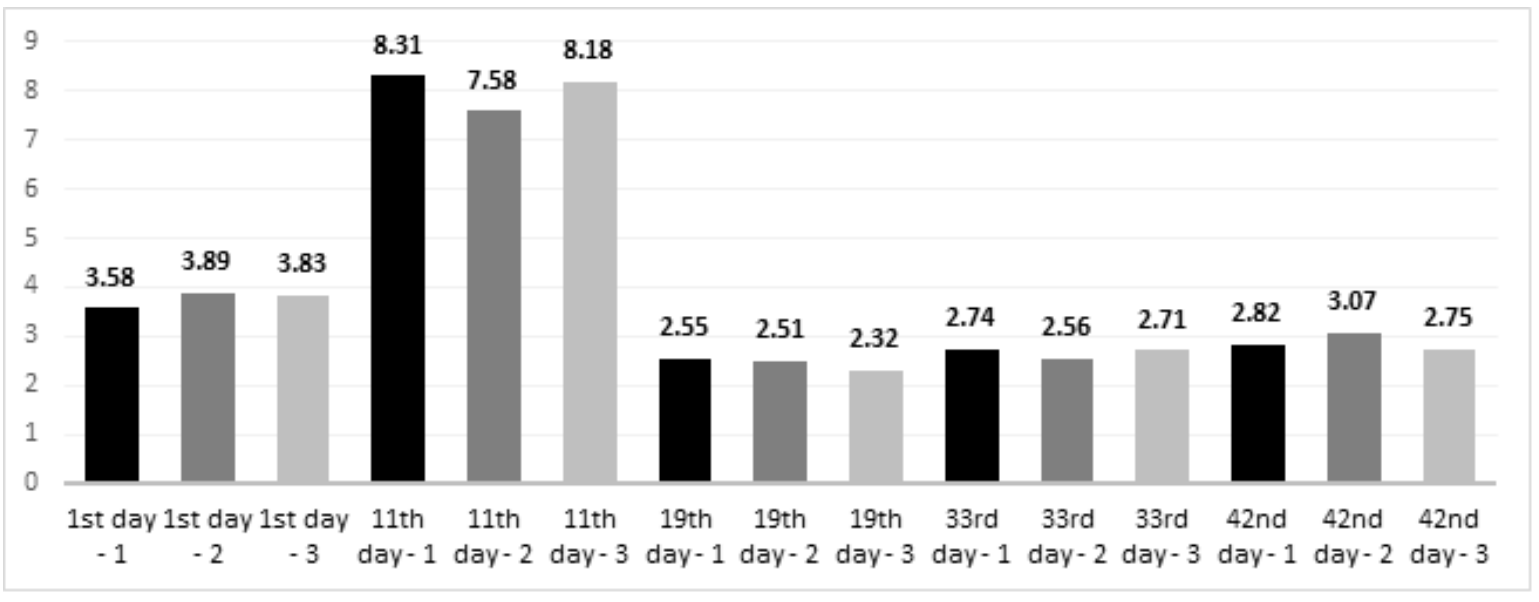

Figure 2. Total nitrogen (\%) in the litter. Notes: 1-control group; 2-group with halloysite in the litter; 3-group with zeolite in the litter; 1st day-stater feed period; 11th day-grower 1 feed period; 19th day-grower 2 feed period; 33rd day-finisher feed period; 42nd day—slaughter day; sampling was performed once on the mentioned days. No significant differences between groups were found $(p>0.05)$; mean values from various days were significantly different, with $p$-value $<0.05$; amount of nitrogen was calculated in $100 \mathrm{~g}$ of dry matter of the litter.

\subsection{Gene Expression}

The relative expression of the intestinal immune response genes analyzed in the cecal mucosa showed statistically significant upregulation of IFNG ( $p=0.03$ for group 2; $p=0.0005$ for group 3 ) and IL10 ( $p=0.006$ for group 2; $p=0.005$ for group 3 ). The addition of zeolite (group 3$)$ significantly increased the expression of IL2 $(p=0.01)$ and NCF1C $(p=0.003)$ genes, and the addition of halloysite (group 2) also increased expression of IL1 $\beta$ $(p=0.05)$. The administration of both substances to litter had a numerical $(p>0.05)$ effect on the reduction of IL17 expression. The relative expression levels of immune-related genes are presented in Figure 3.

The analysis of the host defense peptide genes showed a significant decrease in AvBD1 expression $(p=0.03)$ after the addition of zeolite (group 3$)$ to the litter. There were no significant differences in the expression of genes related to the intestinal barrier. There 
was a numerical increase in CLDN1 expression after the addition of zeolite to the litter. In nutrients-sensing genes group, FFAR2 $(p=0.05)$ and GLUT1 $(p=0.005)$ expression increased significantly in the group with additional halloysite in the litter. There was also a significant decrease in FFAR4 expression in both groups with added minerals ( $p=0.02$ for group 2; $p=0.01$ for group 3). The relative expression levels of host defense genes, barrier function genes and nutrient-sensing genes are presented in Figure 4.

Table 4. Slaughter yield and quality traits of breast and leg muscles of chickens.

\begin{tabular}{|c|c|c|c|c|c|c|c|c|}
\hline \multirow{2}{*}{ Item $^{1}$} & \multicolumn{3}{|c|}{ Group $^{2}$} & \multirow[b]{2}{*}{ SEM } & \multicolumn{4}{|c|}{$p$-Value ${ }^{3}$} \\
\hline & 1 & 2 & 3 & & Total & 1 vs 2 & 1 vs 3 & 2 vs 3 \\
\hline \multicolumn{9}{|c|}{ mean values } \\
\hline Live body weight (g) & 2932.00 & 3070.80 & 3039.50 & 27.67 & 0.096 & 0.056 & 0.123 & 0.597 \\
\hline Carcass weight (g) & $2225.93^{b}$ & $2365.95^{a}$ & $2287.57^{a b}$ & 22.16 & 0.029 & 0.015 & 0.255 & 0.083 \\
\hline Slaughter yield (\%) & $75.91^{\mathrm{ab}}$ & $77.06^{\mathrm{a}}$ & $75.27^{\mathrm{b}}$ & 0.26 & 0.011 & 0.057 & 0.298 & 0.002 \\
\hline Breast muscle (\%) & 31.75 & 32.24 & 30.97 & 0.40 & 0.436 & 0.649 & 0.372 & 0.219 \\
\hline $\mathrm{pH}_{24 \mathrm{~h}}$ & 6.07 & 6.15 & 6.12 & 0.03 & 0.449 & 0.279 & 0.474 & 0.518 \\
\hline $\mathrm{L}^{*}$ & $51.61^{\mathrm{ab}}$ & $52.13^{a}$ & $49.42^{b}$ & 0.53 & 0.081 & 0.721 & 0.082 & 0.015 \\
\hline$a^{*}$ & 2.25 & 2.80 & 3.18 & 0.18 & 0.105 & 0.181 & 0.057 & 0.374 \\
\hline $\mathrm{b}^{*}$ & 4.64 & 5.37 & 4.75 & 0.31 & 0.608 & 0.422 & 0.878 & 0.418 \\
\hline WHC (\%) & $32.97^{\mathrm{a}}$ & $28.58^{b}$ & $36.76^{\mathrm{a}}$ & 1.27 & 0.008 & 0.012 & 0.198 & 0.005 \\
\hline Crude protein (\%) & $22.63^{a}$ & $22.25^{b}$ & $21.76^{\mathrm{c}}$ & 0.07 & $<0.001$ & $<0.001$ & $<0.001$ & $<0.001$ \\
\hline Intramuscular fat (\%) & $2.36^{c}$ & $2.69^{b}$ & $3.09^{a}$ & 0.06 & $<0.001$ & $<0.001$ & $<0.001$ & $<0.001$ \\
\hline Leg muscle (\%) & 20.59 & 19.48 & 20.40 & 0.25 & 0.126 & 0.066 & 0.759 & 0.106 \\
\hline $\mathrm{L}^{*}$ & $45.68^{b}$ & $48.10^{a b}$ & $49.44^{\mathrm{a}}$ & 0.71 & 0.087 & 0.199 & 0.038 & 0.358 \\
\hline$a^{*}$ & 5.02 & 4.68 & 4.06 & 0.31 & 0.448 & 0.602 & 0.236 & 0.467 \\
\hline$b^{*}$ & $4.49^{\mathrm{a}}$ & $1.94^{b}$ & $3.53^{a b}$ & 0.47 & 0.035 & 0.036 & 0.999 & 0.055 \\
\hline WHC (\%) & 32.19 & 33.92 & 35.38 & 0.51 & 0.029 & 0.106 & 0.004 & 0.292 \\
\hline Crude protein (\%) & $19.03^{b}$ & $19.11^{\mathrm{a}}$ & $18.56^{c}$ & 0.05 & $<0.001$ & 0.003 & $<0.001$ & $<0.001$ \\
\hline Intramuscular fat (\%) & $7.17^{\mathrm{a}}$ & $6.99 \mathrm{~b}$ & $7.14^{\mathrm{a}}$ & 0.02 & $<0.001$ & $<0.001$ & 0.337 & $<0.001$ \\
\hline
\end{tabular}

a b c: means in the same line with no common superscript differ between groups; ${ }^{1}, \mathrm{~L}^{*}$, lightness; $\mathrm{a}^{*}$, redness; $\mathrm{b}^{*}$, yellowness; WHC, water-holding capacity; ${ }^{2}$, control group; 2 , halloysite group; 3 , zeolite group; ${ }^{3}$, SEM, standard error of the mean; $p$-value: Total, one-dimensional results; 1 vs 2 , significance between control and halloysite groups; 1 vs 3 , significance between control and zeolite groups; 2 vs 3 , significance between halloysite and zeolite groups; 1 vs 2,1 vs 3,2 vs 3 : $t$-test, $p$-value $<0.05$.

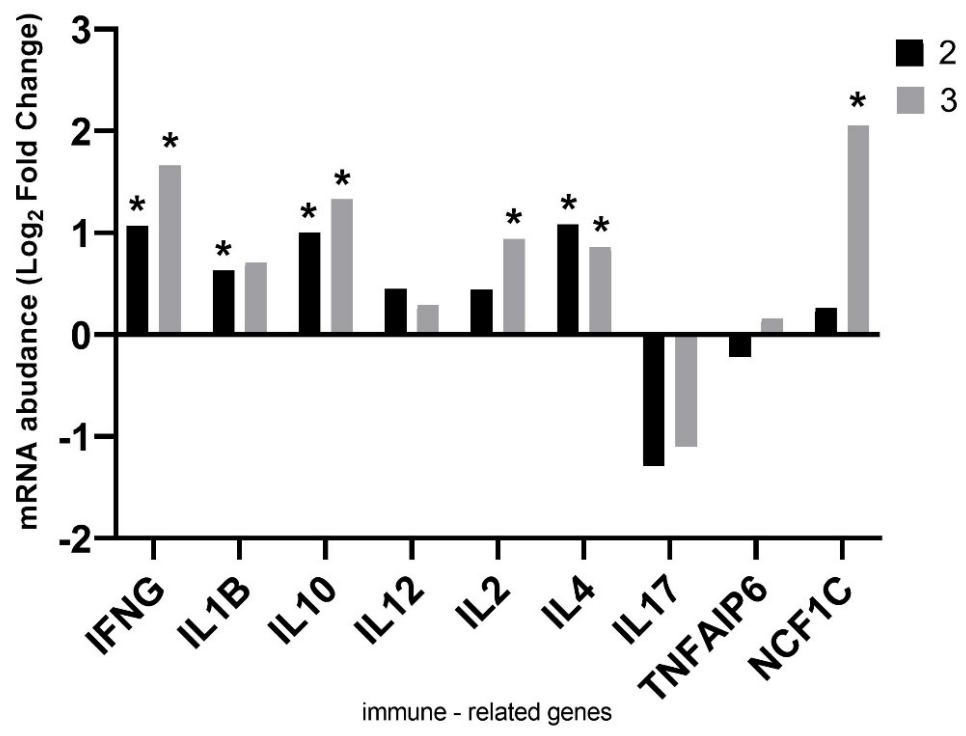

Figure 3. Relative gene expression of immune-related genes in cecal mucosa in chickens fed with the addition of halloysite and zeolite, as well as the addition of pulverized halloysite (group 2) and zeolite (group 3) to the litter. Statistical analysis consisted of comparing the experimental groups with the control group using Student's $t$-test ( ${ }^{*}$ for $p$-value $\left.<0.05\right)$. 


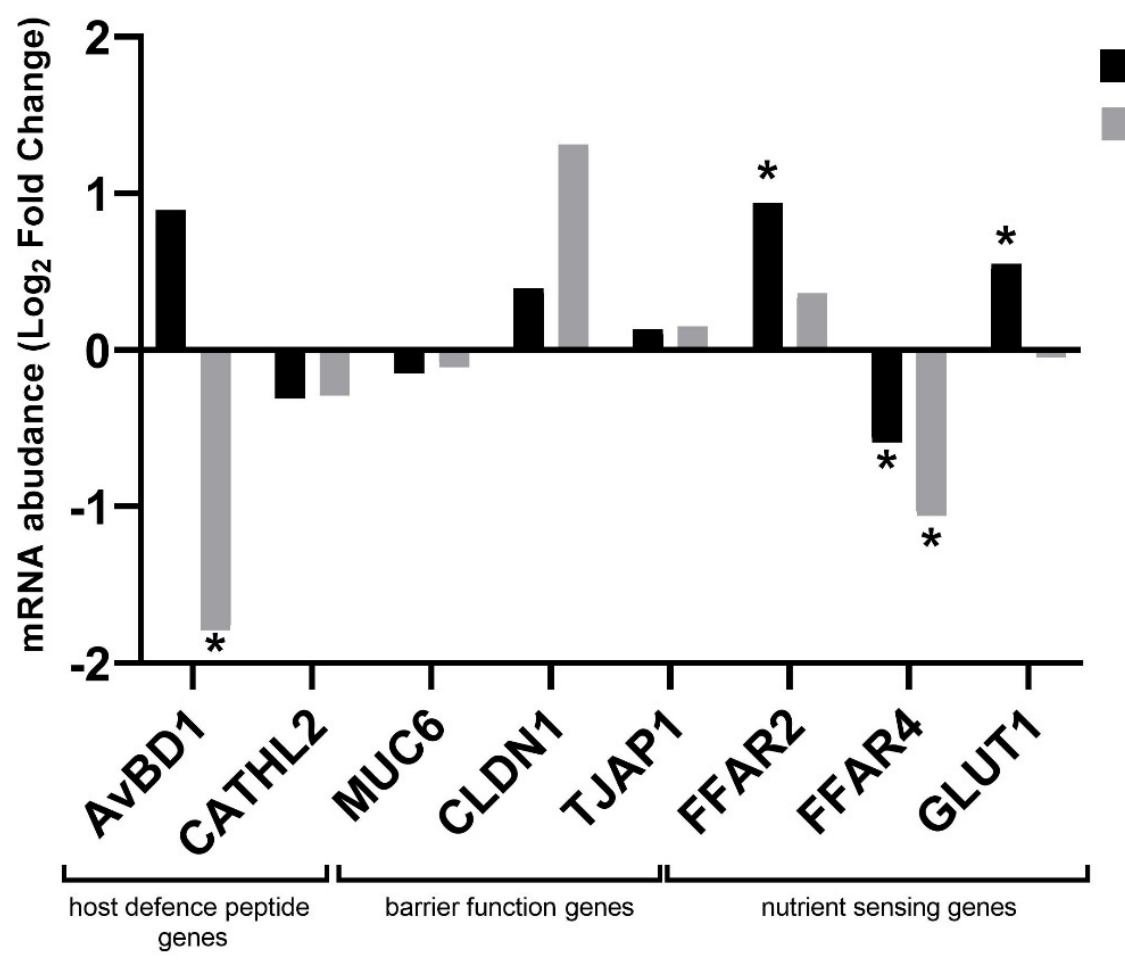

Figure 4. Relative gene expression of host defense peptide genes, barrier function genes and nutrientsensing genes in cecal mucosa in chickens fed with the addition of halloysite and zeolite, as well as the addition of pulverized halloysite (group 2) and zeolite (group 3) to the litter. Statistical analysis consisted of comparing the experimental groups with the control group using Student's $t$-test $\left({ }^{*}\right.$ for $p$-value $<0.05)$.

\section{Discussion}

\subsection{Growth Performance and Litter Traits}

Willis et al. [32] found that a zeolite addition of 2 and 3\% for chickens improved their body weight gain without adversely affecting feed consumption. Our own research did not show any significant differences in body weight gain and feed consumption for the entire rearing period. Only during the feeding of grower 1 and 2 were differences in feed consumption observed; however, this did not affect the feed conversion ratio. In the studies of Bintas et al. [33], natural zeolite levels up to $0.8 \%$ were tested. These authors also showed no statistically significant differences in the production characteristics of chickens. Due to the very low mortality rate in all groups in our own research, the European Broiler Index (EBI) in all groups was considered high and amounted to over 450 . Hence, the example values in the Aviagen guide in 2015 year amounted to approximately 350 . The higher EBI value is very beneficial and indicates a balanced growth and good health status of birds [34].

In the level of total nitrogen in the litter, it was noticed that after 11 days of rearing, there was a visible increase in nitrogen content. At that time, there was a change of feed from starter to grower 1. According to the information in the study of Carvalho et al. [35], the nitrogen level increased after 14 days of rearing broiler chickens, which was caused by higher levels of methionine and cystine in the feed. No such relationships were found in the remaining rearing periods. The lower content of crude protein in the feed also reduced nitrogen excretion [36], which was noted in the authors' own research. Nitrogen excretion is also related to the development and health of the digestive tracts of young chickens and the digestibility of the feeds $[37,38]$. Clays and aluminosilicates can stabilize gases and nitrogen in the manure (litter) [39], which is very important for maintaining appropriate hygienic conditions in production. 


\subsection{Meat Quality Traits}

Less water loss was seen in group 2 in the breast muscles. In group 3, WHC was higher in the leg muscles. The water absorption of meat is related to myofibril proteins, the genotype and the post-slaughter period affect [40]. For example, in group 3, a greater loss of water in the breast muscles was combined with a lower protein content. As described by Xia et al. [40], WHC is highly positively correlated with protein concentration, and there is also a link with the gel structure of proteins. Changes related to WHC or the content of nutrients may be related to the oxidation of proteins, and Hashemi et al. [8] described that the addition of silver nanoparticles with zeolite could affect these features. The authors described the relationship of higher WHC, and lower level of protein oxidation. Analyzing the $\mathrm{pH}$ of the breast muscles, correct values were found in all groups at the level of 6.07-6.15. According to Van Laack et al. [41], the normal pH of breast muscles should be 5.96. Other studies have described normal values in the range 5.5-6.5, and this is associated with changes in the level of glycogen oxidation in meat [42]. The color saturation $\left(\mathrm{L}^{*}\right)$ of the breast muscles in our study was 49.42-52.13. There were no significant differences between the groups, but it could be concluded that the meat was normal, while in the group 3 the meat could be considered normal with a slight deviation towards a light color. According to Pietrase et al. [43], normal breast muscles are characterized by an $L^{*}$ color at the level of 50-56.

\subsection{Gene Expression}

In this study, the effect of the administration of natural minerals on the intestinal response shown in the expression of genes related to intestinal tightness, defense against pathogens, immune status and nutritional transport was also determined. To analyze the effects of supplementation in poultry science, one of the most studied sections in the gastrointestinal tract is the ceca, where most fermentation processes occur. The cecum harbors a more diverse and stable microbiome than illeum. It is therefore of great metabolic importance. Microbiota of this part of intestine shows metabolic activity ensured by intestinal bacteria (including Ruminococcus, Streptococcus, Faecalibacterium, Lactobacillus, and Clostridium), which support fermentation processes and produce short-chain fatty acids (SCFA) (e.g., butyrate) [44]. Chickens have paired cecals, which are habitat for similar bacterial communities. Additionally, in birds there is an organ called cecal tonsils, which is the main immune organ (the largest lymphoid organ of avian gut-associated lymphoid tissue (GALT)) [45]. The mucosa of these intestines contains clusters of lymphoid tissue [46], 1998. Taking into account the biological premises, the expression of genes in the cecal mucosa was analyzed in terms of changes in the gene expression profile related to the immune and metabolic status of the host.

\subsubsection{Immune-Related Genes}

In this study we have shown that the addition of natural minerals gently stimulates the host's immune system (the fold increase in expression for most genes is close to a value of 1). Excessive stimulation of the immune system may have a negative effect on production parameters. In this situation, the host organism redirects the metabolic energy intended for development and growth to maintain the immune system in a state of intense arousal. As described in Kominsky et al. [47], changes resulting from this condition can result in metabolic acidosis or reduced oxygen supply, leading to fundamental changes in tissue metabolism. Due to this fact, it is necessary to simultaneously monitor the production parameters and the levels of gene expression related to the immune system. The analysis of the expression of genes related to the immune response showed an increase in IFNG and IL1 $\beta$ expression. IFNG, apart from its antiviral activity, has important immunoregulatory functions [48]. IL1 $\beta$ is a pro-inflammatory cytokine that also shows protective functions. Intestinal IL1 $\beta$ is secreted into intestinal lumen and is a key mediator of intestinal inflammation. Its expression can be modulated by commensal intestinal microbiota. One mechanism by which microbiota promotes host resistance is stimulation of IL1 $\beta$ expression [49]. The 
increase in IL1 $\beta$ expression in chickens in the groups with the addition of natural minerals may be dependent on the gut microbiota. Stimulation of the intestinal mucosa towards immunomodulation has been shown, as indicated by the positive expression of the proinflammatory cytokine IL12 and the anti-inflammatory IL10 [50]. Increased expression of IL2 and IL4 was observed in our study. IL2 reduces the replication or pathogenicity of many viral pathogens by the mechanism of activating natural killer cells and cytotoxic T lymphocytes [51]. IL4 is considered an important cytokine in tissue repair [52] but also contributes to allergic airway inflammation [53]. Expression of IL17 was not statistically decreased, but it was numerically decreased. This is a beneficial effect of natural minerals because the upregulation of this cytokine may be associated with chronic diseases. As shown in the literature, lung injury may result from an inflammatory response mediated by IL17 [54]. Expression analysis showed a significant increase in the NCF1C gene after administration of the zeolite/halloysite mixture in the feed with the simultaneous administration of the zeolite in the litter. The protein encoded by the NCF1C gene belongs to a group of proteins that make up an enzyme complex called NADPH oxidase, which plays an important role in the immune system [55]. NADPH oxidase is primarily active in phagocytes, which catch and eliminate foreign bacteria and fungi. NADPH oxidase also regulates the activity of neutrophils, which play a key role in adjusting the inflammatory response to optimize the healing process [56]. Our analyses show a beneficial stimulation of the immune system without adversely affecting production parameters.

\subsubsection{Host Defense Peptide Genes}

Defensins play an important role in the host's innate defense, which includes the protection of the epithelium against pathogenic microbes and regulation of the endogenous gut microbiota. The decrease in the gene expression may lead to changes in innate immunity and modification of the intestinal microbiota. As a consequence, this may lead to an increase in the host's susceptibility to disease [57]. In the expression analysis, we showed that in group 2, where the minerals in the feed and the halloysite were added to the litter, the expression increased numerically. In group 3, where zeolite was applied to the litter, the expression significantly decreased. However, an analysis of a panel of immune-related genes showed no disturbance in the organism's immune status.

\subsubsection{Barrier Function Genes}

In order to maintain the integrity of the intestinal barrier, intestinal epithelial cells are tightly bound together by intercellular bridges. Tight connections between epithelial cells are a complex of proteins that includes, inter alia, claudin. Tight junctions ensure the tightness of the barrier between the intestinal microbiota and the host organism [58]. In this way, they protect the body against endotoxemia, which can occur, for example, during diseases. Research has shown that unsealing and impaired functioning of the intestinal barrier of the intestinal epithelium may be the main factor determining inflammation of the gastrointestinal tract or food hypersensitivity [14]. The analysis of the expression of genes related to intestinal integrity in the intestinal mucosa of chickens after the administration of natural minerals in the feed and in the litter showed no negative impact of the given minerals on the gap junctions and intestinal barrier integrity. The expression of CLDN1 was shown to increase numerically when zeolite was added to the litter. Its increased expression leads to the tightening of intestinal epithelial cells.

\subsubsection{Nutrient Sensing Genes}

The cecum, from where the mucosa was collected for analysis of gene expression, plays a key role in maintaining gut health, reusing urine nitrogen and fermenting undigested nutrients [59]. It is involved in the absorption of electrolytes and water, but also allows for prolonged retention of the content. It is a specific reservoir of food content that is delivered from the ileum. Scientific reports indicate that there is a significant correlation between the composition of the microbiota of the cecum and the efficiency of harvesting energy, which 
suggests a strong correlation between bacteria inhabiting the cecum, including the mucosa, and production parameters [60].

Our research involved the analysis of three genes related to nutrient sensing: free fatty acid receptors (FFARs) and glucose transporter (GLUT). Proteins encoded by FFAR2 and FFAR4 genes, whose significant regulation has been demonstrated in this experiment, regulate lipids and glucose metabolism. Loss of function of FFARs, due to the fact that they regulate lipid metabolism, increases the risk of excessive fat gain [61]. Our research shows that the administration of minerals in the feed and, additionally, halloysite in the litter significantly increases FFAR2 expression. FFAR2 is activated by SCFA, which play a significant role in regulating the organisms' energy homeostasis and intestinal immunity. SCFAs are produced by the intestinal microbiota. They are a kind of communicator between the microbiota and the immune system (they are responsible for maintaining balance in antiinflammatory and pro-inflammatory reactions) [62]. Our research suggests altered activity of the intestinal microbiota after the addition of the minerals, but this aspect requires further specific analysis. The proteins encoded by the FFAR4 genes mediate the release of incretin hormones from the epithelium into the lumen of the gut. These include GLP-1 and GIP, which are intestinal hormones that are released upon the response to food intake that inhibit gastric emptying and reduce appetite and food intake [63]. The mechanism is designed to stimulate satiety and reduce further feed intake [64]. The negative regulation of the FFAR4 gene in the intestinal mucosa may be associated with the inhibition of the activity of incretin hormones and thus may be associated with the increase in body weight of the birds in the group where the minerals were added to the feed and litter. GLUTs are involved in the absorption of glucose through the epithelial cell membrane. Glucose uptake is important due to the fact that it acts as a fuel and an important metabolic substrate in the organism. Group 2 showed a significant increase in GLUT1 expression, which seems to be beneficial in terms of its function. GLUT1 facilitates basal glucose uptake, which is necessary for growth and development in most cells [65].

\section{Conclusions}

The use of halloysite and zeolite in the ratio of $1: 1(0.5-2 \%$ in the feed) in the experimental groups, with the simultaneous addition of halloysite at the level of $650 \mathrm{~g} / \mathrm{m}^{2}$ and zeolite $\left(650 \mathrm{~g} / \mathrm{m}^{2}\right)$ to the straw pellet litter, had no negative effect on growth performance of broiler chickens. Some beneficial effects were detected, such as better water-holding capacity in the breast muscles of chickens kept on litter with halloysite. This parameter is important from the point of view of meat-processing technology. Additionally, the results suggested that natural minerals have immunostimulating properties (an increase in Th1 responses and pro-inflammatory cytokines) and immunoregulatory properties (an increase in Th2 responses and anti-inflammatory cytokines). On the basis of the obtained results, it can be suggested that the addition of aluminosilicates to the feed and litter allowed for the production of broiler chickens in a sustainable manner, without adversely affecting most of the tested traits and positive results of immunostimulating properties, which allows for the recommendation of natural feed and litter additives for safe poultry production. Considering the manufacturer's market, zeolite is more available and better known, which may indicate that it is more recommended than halloysite. However, the quality of the meat and, above all, the slaughter yield indicate the use of halloysite being more suitable in the litter, as these values were more favorable. The analysis of the obtained results prompts further research into the optimal dose of natural minerals, which will allow for the improvement of production.

Author Contributions: Conceptualization, M.B.; methodology, M.B., M.S. and M.A.; software, J.B. and A.D.; validation, M.B., J.B. and A.D.; formal analysis, J.B. and A.D.; investigation, M.B.; resources, M.B.; data curation, J.B. and A.D.; writing—original draft preparation, M.B., J.B. and A.D.; writing-review and editing, M.S. and M.A.; visualization, M.B.; supervision, M.S. and M.A.; project administration, M.B. and J.B.; funding acquisition, M.B. All authors have read and agreed to the published version of the manuscript. 
Funding: This research was funded by the Agency for the Restructuring and Modernization of Agriculture (Poland) from the project "Safe Farm". The APC was funded by the internal resources of the Faculty of Animal Breeding and Biology, UTP in Bydgoszcz (BN-8/2021).

Institutional Review Board Statement: According to Directive no. 2010/63/EU, the consent of the Ethics Committee was not required. According to legal requirements, the slaughter of animals is not a procedure requiring approval from the Ethics Committee; it was performed in accordance with the applicable rules regarding the protection of animals and their welfare at the time of slaughter. In addition, it was not necessary obtain the consent of the Ethics Committee as dictated by Regulation 13/2016 of the National Ethics Committee for Animal Experiments.

Informed Consent Statement: Not applicable.

Data Availability Statement: All the data, methods and results of the statistical analyses are reported in this paper. We remain at your disposal in the case of any questions.

Acknowledgments: This research was funded by the project "Safe Farm-innovative products, processes and marketing in the production of broiler chickens", implemented in 2020-2022 and co-financed from the European Agricultural Fund for Rural Development: Europe investing in rural areas". The authors thank the Kuyavian-Pomeranian Association of Poultry Breeders and Egg Producers (Poland) (www.bezpiecznaferma.pl, accessed date: 20 July 2021) for the opportunity to conduct research and implement their results for further poultry management practice, as well as the Agency for the Restructuring and Modernization of Agriculture (Poland; founder of project). We thank the Laboratory of Chemical Research and Instrumental Analyzes of the Faculty of Animal Breeding and Biology of the UTP in Bydgoszcz for their support in the preparation of the analyses of $\mathrm{pH}$ and total nitrogen in the litter.

Conflicts of Interest: The authors declare no conflict of interest.

\section{References}

1. Juzaitis-Boelter, C.P.; Benson, A.P.; Ahammad, M.U.; Jones, M.K.; Ferrel, J.; Davis, A.J. Dietary inclusion of AZOMITE improves feed efficiency in broilers and egg production in laying and broiler breeder hens. Poult. Sci. 2021, 101144, in press. [CrossRef]

2. Eroglu, N.; Emekci, M.; Athanassiou, C.G. Applications of natural zeolites on agriculture and food production. J. Sci. Food Agric. 2017, 97, 3487-3499. [CrossRef] [PubMed]

3. Radziemska, M.; Mazur, Z.; Jeznach, J. Influence of Applying Halloysite and Zeolite to Soil Contaminted with Nickel on the Content of Selected Elements in Maize (Zea mays L.). Chem. Eng. Trans. 2013, 32, 301-306.

4. Schneider, A.F.; Zimmermann, O.F.; Gewehr, C.E. Zeolites in poultry and swine production. Cienc. Rural 2017, 47 , e20160344. [CrossRef]

5. Meluzzi, A.; Claudio, F.; Folegatti, E.; Sirri, F. Survey of chicken rearing conditions in Italy: Effects of litter quality and stocking density on productivity, foot dermatitis and carcase injuries. Br. Poult. Sci. 2008, 49, 257-264. [CrossRef]

6. Świątkiewicz, S.; Arczewska-Włosek, A.; Józefiak, D. The nutrition of poultry as a factor affecting litter quality and foot pad dermatitis-An updated review. J. Anim. Physiol. Anim. Nutr. 2017, 101, e14-e20. [CrossRef]

7. Wang, K.H.; Shi, S.R.; Dou, T.C.; Sun, H.J. Effect of a free-range raising system on growth performance, carcass yield, and meat quality of slow-growing chicken. Poult. Sci. 2009, 88, 2218-2223. [CrossRef] [PubMed]

8. Hashemi, S.R.; Davoodi, D.; Dastar, B.; Bolandi, N.; Smaili, M.; Mastani, R. Meat Quality Attributes of Broiler Chickens Fed Diets Supplemented with Silver Nanoparticles Coated on Zeolite. Poult. Sci. J. 2014, 4, 183-193.

9. Mallek, Z.; Fendri, I.; Khannous, L.; Hassena, A.B.; Traore, A.I.; Ayadi, M.A.; Gdoura, R. Effect of zeolite (clinoptilolite) as feed additive in Tunisian broilers on the total flora, meat texture and the production of omega 3 polyunsaturated fatty acid. Lipids Health Dis. 2012, 11, 35. [CrossRef]

10. Safei, M.; Boldaji, F.; Dastar, B.; Hassani, S.; Mutalib, M.S.A.; Rezaei, R. Effects of inclusion kaolin, bentonite and zeolite in dietary on chemical composition of broiler chickens meat. Asian J. Anim. Vet. Adv. 2014, 9, 56-63. [CrossRef]

11. Opaliński, S.; Korczyński, M.; Szołtysik, M.; Dobrzański, Z.; Kołacz, R. Application of aluminosilicates for mitigation of ammonia and volatile organic compound emissions from poultry manure. Open Chem. 2015, 13, 967-973. [CrossRef]

12. Patterson, J.A.; Burkholder, K.M. Application of prebiotics and probiotics in poultry production. Poult. Sci. 2003, 82, 627-631. [CrossRef]

13. Hajati, H.; Rezaei, M. The application of prebiotics in poultry production. Int. J. Poult. Sci. 2010, 9, 298-304. [CrossRef]

14. Groschwitz, K.R.; Hogan, S.P. Intestinal barrier function: Molecular regulation and disease pathogenesis. J. Allergy Clin. Immunol. 2009, 124, 3-20. [CrossRef]

15. Banaszak, M.; Biesek, J.; Bogucka, J.; Dankowiakowska, A.; Olszewski, D.; Bigorowski, B.; Grabowicz, M.; Adamski, M. Impact of aluminosilicates on productivity, carcass traits, meat quality and jejunum morphology of broiler chickens. Poult. Sci. 2020, 99, 7169-7177. [CrossRef] 
16. Biesek, J.; Banaszak, M.; Adamski, M. Ducks' Growth, Meat Quality, Bone Strength, and Jejunum Strength Depend on Zeolite in Feed and Long-Term Factors. Animals 2021, 11, 1015. [CrossRef]

17. Sukovata, L.; Kolk, A.; Karolewski, P.; Smolewska, M.; Isidorov, V. Wpływ żerowania owadów liściożernych sosny na skład chemiczny igiliwa, ściółki i gleby. Sylwan 2010, 154, 639-648. (In Polish)

18. Polska Norma PN-ISO 10390:1997. Jakość gleby-Oznaczanie pH. In Polski Komitet Normalizacyjny; Polski Komitet Normalizacyjny: Warsaw, Poland, 1997. (In Polish)

19. Polska Norma PN-EN ISO 5983-1:2006. Oznaczanie zawartości azotu i obliczanie zawartości białka ogólnego. In Polski Komitet Normalizacyjny; Polski Komitet Normalizacyjny: Warsaw, Poland, 2006. (In Polish)

20. Budnik, S. The Effect of $\mathrm{Zn}, \mathrm{Cu}$, and Mn Chelates of Hydroxy Analogue of Methionine on Performance and Meat Quality of Broiler Chicken. Ph.D. Thesis, UTP_University of Science and Technology in Bydgoszcz, Bydgoszcz, Poland, November 2017. (In Polish)

21. Sławińska, A.; Dunisławska, A.; Płowiec, A.; Radomska, M.; Lachmanska, J.; Siwek, M.; Tavaniello, S.; Maiorano, G. Modulation of microbial communities and mucosal gene expression in chicken intestines after galactooligosaccharides delivery In Ovo. PLoS ONE 2019, 14, e0212318. [CrossRef]

22. Ye, J.; Coulouris, G.; Zaretskaya, I.; Cutcutache, I.; Rozen, S.; Madden, T.L. Primer- BLAST: A tool to design target-specific primers for polymerase chain reaction. BMC Bioinform. 2012, 13, 134. [CrossRef]

23. Zhang, J.; Gao, Y.Y.; Huang, Y.Q.; Fan, Q.; Lu, X.T.; Wang, C.K. Selection of housekeeping genes for quantitative gene expression analysis in yellow-heathered broilers. Ital. J. Anim. Sci. 2018, 17, 540-546. [CrossRef]

24. Qin, N.; Shan, X.; Sun, X.; Liswaniso, S.; Chimbaka, I.M.; Xu, R. Evaluation and Validation of the Six Housekeeping Genes for Normalizing Mrna Expression in the Ovarian Follicles and Several Tissues in Chicken. Braz. J. Poult. Sci. 2020, $22,1-12$. [CrossRef]

25. Sevane, N.; Bialade, F.; Velasco, S.; Rebolé, A.; Rodríguez, M.L.; Ortiz, L.T.; Canon, J.; Dunner, S. Dietary inulin supplementation modifies significantly the liver transcriptomic profile of broiler chickens. PLoS ONE 2014, 9, e98942. [CrossRef] [PubMed]

26. Brisbin, J.T.; Gong, J.; Parvizi, P.; Sharif, S. Effects of lactobacilli on cytokine expression by chicken spleen and cecal tonsil cells. Clin. Vaccine Immunol. 2010, 17, 1337-1343. [CrossRef] [PubMed]

27. Rothwell, L.; Young, J.R.; Zoorob, R.; Whittaker, C.A.; Hesketh, P.; Archer, A.; Smith, A.L.; Kaiser, P. Cloning and characterization of chicken IL-10 and its role in the immune response to Eimeria maxima. J. Immunol. 2004, 173, 2675-2682. [CrossRef]

28. Sławińska, A.; Mendes, S.; Dunisławska, A.; Siwek, M.; Zampiga, M.; Sirri, F.; Meluzzi, A.; Tavaniello, S.; Maiorano, G. Avian model to mitigate gut-derived immune response and oxidative stress during heat. BioSystems 2019, 178, 10-15. [CrossRef] [PubMed]

29. Sławińska, A.; Siwek, M.Z.; Bednarczyk, M.F. Effects of synbiotics injected in ovo on regulation of immune-related gene expression in adult chickens. Am. J. Vet. Res. 2014, 75, 997-1003. [CrossRef] [PubMed]

30. Livak, K.J.; Schmittgen, T.D. Analysis of relative gene expression data using real-time quantitative PCR and the 2(-Delta Delta C(T)) Method. Methods 2001, 25, 402-408. [CrossRef]

31. Vandesompele, J.; De Preter, K.; Pattyn, F.; Poppe, B.; Van Roy, N.; De Paepe, A.; Speleman, F. Accurate normalization of real-time quantitative RT-PCR data by geometric averaging of multiple internal control genes. Genome Biol. 2002, 3, RESEARCH0034. [CrossRef]

32. Willis, W.L.; Quarles, C.L.; Fagerberg, D.J. Evaluation of Zeolites Fed to Male Broiler Chickens. Poult. Sci. 1982, 61, 438-442. [CrossRef]

33. Bintas, E.; Bozkurt, M.; Kucukyilmaz, K.; Konak, R.; Cinar, M.; Aksit, H.; Seyrek, K.; Catli, A.U. Efficacy of Supplemental Natural Zeolite in Broiler Chickens Subjected to Dietary Calcium Deficiency. Ital. J. Anim. Sci. 2014, 13, 3141. [CrossRef]

34. Kryeziu, A.J.; Mestani, N.; Beisha, S.; Kamberi, M.A. The European performance indicators of broiler chickens as influenced by stocking density and sex. Agron. Res. 2018, 16, 483-491.

35. Carvalho, G.B.; Santos Neto, L.D.; Martins, J.M.S.; Pereira, N.M.; Falleiros, M.B.; Arnhold, E.; Café, M.B. Litter quality of broiler fed with to different levels of sulfur amino acid. J. Anim. Behav. Biometeorol. 2018, 6, 21-28. [CrossRef]

36. Kriseldi, R.; Tillman, P.B.; Jiang, Z.; Dozier, W.A., III. Effects of feeding reduced crude protein diets on growth performance, nitrogen excretion, and plasma uric acid concentration of broiler chicks during the starter period. Poult. Sci. 2018, 97, 1614-1626. [CrossRef]

37. Macelline, S.P.; Wickramasuriya, S.S.; Cho, H.M.; Kim, E.; Shin, T.K.; Hong, J.S.; Kim, J.C.; Pluske, J.R.; Choi, H.J.; Hing, Y.G.; et al Broilers fed a low protein diet supplemented with synthetic amino acids maintained growth performance and retained intestinal integrity while reducing nitrogen excretion when raised under poor sanitary conditions. Poult. Sci. 2020, 99, 949-958. [CrossRef]

38. Sittiya, J.; Yamauchi, K.; Nimanong, W.; Thongwittaya, N. Influence of Levels of Dietary Fiber Sources on the Performance, Carcass Traits, Gastrointestinal Tract Development, Fecal Ammonia Nitrogen, and Intestinal Morphology of Broilers. Rev. Bras. Cienc. 2020, 22. [CrossRef]

39. Nadziakiewicza, M.; Kehoe, S.; Micek, P. Physico-Chemical Proporties of Clay Minerals and Their Use as a Health Promoting Feed Additive. Animals 2019, 9, 714. [CrossRef] [PubMed]

40. Xia, T.; Cao, Y.; Chen, X.; Zhang, Y.; Xue, X.; Han, M.; Li, L.; Zhou, G.; Xu, X. Effects of chicken myofibrillar protein concentration on protein oxidation and water holding capacity of its heat-induced gels. J. Food Meas. Charact. 2018, 12, 2302-2312. [CrossRef] 
41. Van Laack, R.L.J.M.; Liu, C.-H.; Smith, M.O.; Loveday, H.D. Characteristics of Pale, Soft, Exudative Broiler Breast Meat. Poult. Sci. 2000, 79, 1057-1071. [CrossRef] [PubMed]

42. Manyeula, F.; Mlambo, V.; Marume, U.; Sebola, N.A. Partial replacement of soybean products with canola meal in indigenous chicken diets: Size of internal organs, carcass characteristics and breast meat quality. Poult. Sci. 2020, 99, 256-262. [CrossRef]

43. Pietrase, E.; Erasmus, S.W.; Uushona, T.; Hoffman, L.C. Black soldier fly (Hermetia illucens) pre-puapae meal as a dietary protein source for broiler production ensures a tasty chicken with standard meat quality for every pot. J. Sci. Food Agric. 2018, 99, 893-903. [CrossRef]

44. Borda-Molina, D.; Matis, G.; Mackei, M.; Neogrady, Z.; Huber, K.; Seifert, J.; Camarinha-Silva, A. Caeca Microbial Variation in Broiler Chickens as a Result of Dietary Combinations Using Two Cereal Types, Supplementation of Crude Protein and Sodium Butyrate. Front. Microbiol. 2021, 11, 617800. [CrossRef] [PubMed]

45. Moral, M.G.D.; Fonfria, J.; Varas, A.; Jimenez, E.; Moreno, J.; Zapata, A.G. Appearance and development of lymphoid cells in the chicken (Gallus gallus) caecal tonsil. Anat. Rec. 1998, 250, 182-189. [CrossRef]

46. Kitagawa, H.; Hiratsuka, Y.; Imagawa, T.; Uehara, M. Distribution of lymphoid tissue in the caecal mucosa of chickens. J. Anat 1998, 192, 293-298. [CrossRef] [PubMed]

47. Kominsky, D.J.; Campbell, E.L.; Colgan, S.P. Metabolic shifts in immunity and inflammation. J. Immunol. 2010, $184,4062-4068$. [CrossRef] [PubMed]

48. Samuel, C.E. Antiviral Actions of Interferons. Clin. Microbiol. Rev. 2001, 14, 778-809. [CrossRef]

49. Khosravi, A.; Mazmanian, S.K. Disruption of the gut microbiome as a risk factor for microbial infections. Curr. Opin. Microbiol. 2017, 16, 221-227. [CrossRef]

50. Ma, X.; Yan, W.; Zheng, H.; Du, Q.; Zhang, L.; Ban, Y.; Li, N.; Wei, F. Regulation of IL-10 and IL-12 production and function in macophages and dendritic cells. F1000Res 2015, 4, PMC4754024. [CrossRef]

51. Susta, L.; Diel, D.G.; Courtney, S.; Cardenas-Garcia, S.; Sundick, R.S.; Miller, P.J.; Brown, C.C.; Afonso, C.L. Expression of chicken interleukin-2 by a highly virulent strain of Newcastle disease virus leads to decreased systemic viral load but does not significantly affect mortality in chickens. Virol. J. 2015, 12, 122. [CrossRef]

52. Salmon-Ehr, V.; Ramont, L.; Godeau, G.; Birembaut, P.; Guenounou, M.; Bernard, P.; Maquart, F.-X. Implication of Interleukin-4 in Wound Healing. Lab. Investig. 2000, 80, 1337-1343. [CrossRef] [PubMed]

53. Gour, N.; Wills-Karp, M. IL-4 and IL-13 Signaling in Allergic Airway Disease. Cytokine 2015, 75, 68-78. [CrossRef]

54. Tan, H.-L.; Rosenthal, M. IL-17 in lung disease: Friend or foe? Thorax 2013, 68, 788-790. [CrossRef]

55. Panday, A.; Sahoo, M.K.; Osorio, D.; Batra, S. NADPH oxidases: An overview from structure to innate immunity-associated pathologies. Cell Mol. Immunol. 2015, 12, 5-23. [CrossRef]

56. Ulfig, A.; Leichert, L.I. The effects of neutrophil-generated hypochlorous acid and other hypohalous acids on host and pathogens. Cell Mol. Life Sci. 2021, 78, 385-414. [CrossRef]

57. Cadwell, K.; Niranji, S.S.; Armstrong, V.L.; Mowbray, C.A.; Bailey, R.; Watson, K.A.; Hall, J. AvDB1 nucleotide polymorphisms, peptide antimicrobial activities and microbial colonisation of the broiler chicken gut. BMC Genom. 2017, 18, 637. [CrossRef] [PubMed]

58. Vancamelbeke, M.; Vermeire, S. The intestinal barier: A fundamental role in health and disease. Expert Rev. Gastroenterol. Hepatol. 2017, 11, 821-834. [CrossRef]

59. Svihus, B.; Choct, M.; Classen, H.L. Function and nutritional roles of the avian caeca: A review. World Poult. Sci. J. 2013, 69, 249-264. [CrossRef]

60. Apajalahti, J.; Rinttila, T.; Kettunen, A. Does the composition of intestinal microbiota determine or reflect feed conversion efficieny? In Proceedings of the 23rd Australian Poultry Science Symposium, Sydney, Autralia, 19-22 February 2012; pp. 32-39.

61. Meslin, C.; Desert, C.; Callebaut, I.; Djari, A.; Klopp, C.; Pitel, F.; Leroux, S.; Martin, P.; Froment, P.; Guilbert, E.; et al. Expanding Duplication of Free Fatty Acid Receptor-2 (GPR43) Genes in the Chicken Genome. Genome Biol. Evol. 2015, 7, 1332-1348. [CrossRef] [PubMed]

62. Chambers, E.S.; Preston, T.; Frost, G.; Morrison, D.J. Role of Gut Microbiota-Generated Short-Chain Fatty Acids in Metabolic and Cardiovascular Health. Curr. Nutr. Rep. 2018, 7, 198-206. [CrossRef]

63. Ahren, B.; Carr, R.; Deacon, C.F. Chapter Seven-Incretin Hormone Secretion Over the Day. Vitam. Horm. 2010, 84, 203-220. [PubMed]

64. Baggio, L.L.; Drucker, D.J. Biology of Incretins: GLP-1 and GIP. Gastroenterology 2007, 132, 2131-2157. [CrossRef] [PubMed]

65. Kono, T.; Nishida, M.; Nishiki, Y.; Seki, Y.; Sato, K.; Akiba, Y. Characterisation of glucose transporter (GLUT) gene expression in broiler chickens. Br. Poult. Sci. 2005, 46, 510-515. [CrossRef] [PubMed] 